\title{
The Plant-Derived Compound Resveratrol in Brain Cancer: A Review
}

\author{
Terezia Kiskova $^{1}$, Peter Kubatka ${ }^{2} \mathbb{D}$, Dietrich Büsselberg ${ }^{3 \oplus}$ and Monika Kassayova ${ }^{1, *}$ \\ 1 Department of Animal Physiology, Institute of Biology and Ecology, Faculty of Science, Pavol Jozef Safarik \\ University, 04154 Kosice, Slovakia; terezia.kiskova@upjs.sk \\ 2 Department of Medical Biology and Biomedical Center Martin, Jessenius Faculty of Medicine, Comenius \\ University in Bratislava, 03601 Martin, Slovakia; peter.kubatka@uniba.sk \\ 3 Department of Physiology and Biophysics, Weill Cornell Medicine in Qatar, Education City, Qatar \\ Foundation, Doha 24144, Qatar; dib2015@qatar-med.cornell.edu \\ * Correspondence: monika.kassayova@upjs.sk
}

Received: 28 December 2019; Accepted: 16 January 2020; Published: 19 January 2020

\begin{abstract}
Despite intensive research, malignant brain tumors are among the most difficult to treat due to high resistance to conventional therapeutic approaches. High-grade malignant gliomas, including glioblastoma and anaplastic astrocytoma, are among the most devastating and rapidly growing cancers. Despite the ability of standard treatment agents to achieve therapeutic concentrations in the brain, malignant gliomas are often resistant to alkylating agents. Resveratrol is a plant polyphenol occurring in nuts, berries, grapes, and red wine. Resveratrol crosses the blood-brain barrier and may influence the central nervous system. Moreover, it influences the enzyme isocitrate dehydrogenase and, more importantly, the resistance to standard treatment via various mechanisms, such as O6-methylguanine methyltransferase. This review summarizes the anticancer effects of resveratrol in various types of brain cancer. Several in vitro and in vivo studies have presented promising results; however, further clinical research is necessary to prove the therapeutic efficacy of resveratrol in brain cancer treatment.
\end{abstract}

Keywords: resveratrol; brain cancer; glioblastoma; drug resistance

\section{Resveratrol}

Resveratrol (RES) is a well-known polyphenol found in many plants, such as grapes (Vitis vinifera), mulberries (Morus sp.), and peanuts (Arachis hypogaea) [1]. It is a phytoalexin produced by spermatophytic plants in response to stress, injury, or UV radiation, or by fungal infection (e.g., Botrytis cinerea) and/or another pathogen [2-4]. The effects of different biotic and abiotic agents on the induced synthesis of RES in various plants have been studied. RES biosynthesis in plants occurs via the phenylalanine pathway [4]. The end product is synthesized as trans form, which may isomerize to cis form, or to trans and cis-piceid due to resveratrol 3-O-beta-glycosyltransferases [5]. Moreover, stilbene synthesis pathway is a side chain of the phenylpropanoid pathway, which may be considered an extension of the flavonoid pathway [6,7].

RES was first isolated in 1939 by Michio Takaoka from the root of Veratrum grandiflorum O. Loes [8]. In 1963, RES was defined as one of the chemical constituents of Polygonum cuspidatum (Ko-jo-kon) [9]. In 1976, the first reported detection method of trans-resveratrol has been described [10]. Thereafter, RES fell into oblivion until 1992, when Renaud and de Lorgeril described for the first time the "French paradox"-[11]. The "French paradox" is based on epidemiological data from French people who had a low incidence of coronary heart disease despite a high intake of dietary cholesterol and saturated fat. Actually, France is still a country with low coronary heart disease incidence and mortality when 
compared to the USA, UK, or Sweden [12-14]. During the same year, the concentration of RES in selected wines was measured [15]. In 2001, a study was carried out where the authors found an association between low to moderate wine intake and lower mortality from cardiovascular and cerebrovascular diseases [16]. After these observations, great attention has been paid to the French paradox and thousands of studies have been performed on various aspects of it [12].

\subsection{Chemical Structure}

Knowing the chemical structure of RES (3,4',5-trihydroxy-trans-stilbene) is important for understanding its biological activity in living organisms. Due to the presence of more than one phenol group [17], RES belongs to the polyphenols [18]. RES is a stilbenoid polyphenol, possessing two phenol rings linked by an ethylene bridge [19]. Polyphenols often have antioxidant properties because they can react with free radicals and form a stable molecule that is less toxic than the radical itself $[20,21]$. Although the presence of a double 'bridge' makes it possible to form both the cis and trans forms of RES (Figure 1), the trans isomer is spatially more stable than the cis isomer [2]. Other minor conjugated forms containing 1-2 methyl groups (pterostilbene), a sulfate group (trans-resveratrol-3-sulfate), or a fatty acid have also been identified [22]. In spectrophotometric analysis, the maximum absorbance of trans-resveratrol is at approximately $304 \mathrm{~nm}$, with cis-resveratrol at $286 \mathrm{~nm}$ [23]. The trans isomer is commercially available and converts to the cis form when exposed to UV radiation [24]. The stability of trans-resveratrol is influenced by various chemical and physical factors, e.g., light exposure, $\mathrm{pH}$ above 6.8 , or temperature above $37^{\circ} \mathrm{C}$ can cause degradation [25].

A

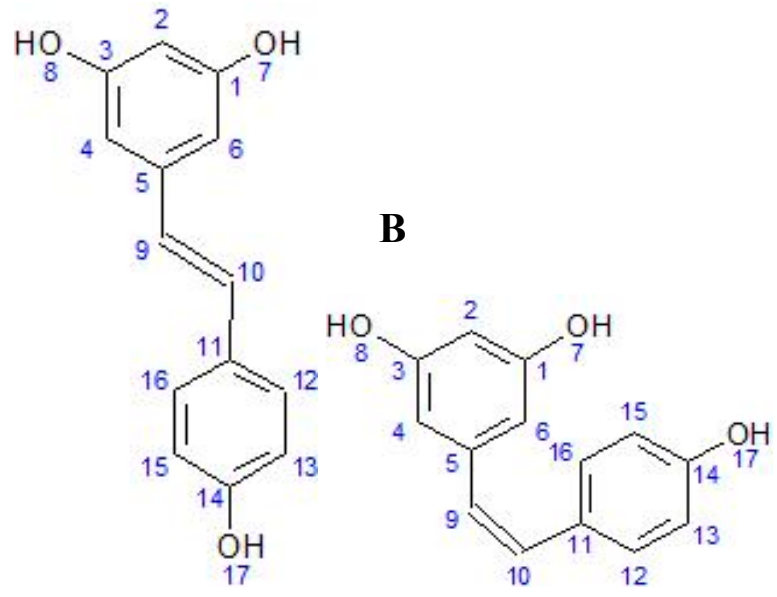

Figure 1. Chemical formula of trans (A) and cis (B) resveratrol (ACD/ChemSketch $\left.{ }^{\circledR}\right)$.

RES is an off-white powder (extracted by methanol), insoluble in water, but dissolves in ethanol or dimethylsulfoxide (DMSO) [26]. It has a melting point of $253-255^{\circ} \mathrm{C}$ and a molecular weight of $228.25 \mathrm{~g} / \mathrm{mol}[2]$.

\subsection{Metabolism of Resveratrol and Biotransformation}

Glycosylation protects RES from oxidative degradation-glycosylated RES is more stable and soluble and readily absorbed in the human gastrointestinal tract [27]. The metabolism of RES is a complex process, involving various pathways, predominantly the conjugation to glucuronides and sulfates in phase II. Both isomers of RES undergo glucuronidation by uridine-diphosphate-glucuronosyltransferase (UGT) to two corresponding glucuronides, 3'-O-glucuronide and 4'-O-glucuronide [22], accounting for its predominant urine excretion [28]. Moreover, in humans, RES is subject to sulfate conjugation by sulfotransferases to form resveratrol-3'-O-sulfate and resveratrol-4'-O-sulfate [22,29]. Abundant trans-resveratrol-3-O-glucuronide and trans-resveratrol-3-sulfate were identified in rat urine, mouse 
serum, and incubations with rat and human hepatocytes [30]. Several other sulfate conjugates ( $4^{\prime}$-sulfate, 3,5-disulfate, 3,4'-disulfate, 3,4', 5-trisulfate) have been identified in the rat [22].

Some RES metabolites are derived from intestinal bacterial metabolism. Dihydroresveratrol was also later identified in rat urine [31], plasma [32], and, most importantly, in mammalian fecal bacterial species [33]. These RES conjugates are then either absorbed by the intestine or excreted in the urine. Up to $50 \%$ of the RES dose can be metabolized in this way [34].

\subsection{Accumulation of Resveratrol in Tissues}

After entering into an organism, the RES in plasma reaches a half-life of 8-14 min; however, for its metabolites it is around $9.2 \mathrm{~h}$ [28]. RES binds to some proteins and protein transporters in the blood stream, to serum albumin or to lipoproteins in the order high-density lipoprotein (HDL) $<$ low-density lipoprotein (LDL) < very low-density lipoprotein (VLDL) $[35,36]$. The absorption of RES occurs by passive diffusion [37] or by transport via ion channels [38] to pass through the cell membrane, allowing its intracellular biological action $[39,40]$.

After oral administration, RES is absorbed [41] and accumulates in various organs, such as the stomach [42], intestines, or liver [28,30,42-44], as sites of its extensive absorption and metabolism [45]. RES (and its metabolites) is able to accumulate in target cells or organs of various diseases [46] including cancer, such as breast cancer tissue [47,48] and colorectal [49,50] or leukemia cancer cells [51]. RES and its metabolites accumulate in myocardial tissue [52] and even in the ocular tissues after oral administration [53]. However, no RES accumulation in the tumor tissue of neuroblastoma in athymic mice was observed [54].

\subsection{Bioavailability of Resveratrol and Potential Side Effects}

Over the past few decades, RES has received widespread attention as a preventive agent for numerous diseases. However, low bioavailability limits its use. After oral administration in humans, up to $75 \%$ of RES is absorbed, possibly by transepithelial diffusion [34]. However, oral bioavailability is low $(<1 \%)$ due to rapid and extensive metabolism in the intestine and liver [55-57]. Thus, increasing the bioavailability is one of the aims nowadays. As has been shown, when loaded in casein nanoparticles, the oral availability of RES increased up to 10 times [58]. Various methodological approaches have been developed in recent years. These include several delivery systems such as the encapsulation of RES in lipid nanocarriers or liposomes, emulsions, micelles, insertion into polymeric nanoparticles, solid dispersions, and nanocrystals [59,60]. For example, the bioavailability of RES from the grapevine shoot extract Vineatrol30 has been significantly increased using a liquid micellar formulation, without any treatment-related adverse effects, making it a suitable system for improved supplementation [61]. On the other hand, the bioavailability of RES delivered through oral mucosa may be significantly higher than by swallowing, as determined by the fraction of the initial RES intake in the blood and, under metabolized form, in the urine [62].

Numerous studies described various side effects of RES [19,63,64]. In a single high dose (500 mg) of RES in 15 healthy volunteers under fasting conditions, no side effects were seen after $24 \mathrm{~h} \mathrm{[57]}$. However, long-term administration of RES at a dose of $2.5 \mathrm{~g}$ per day led to diarrhea, vomiting, or nausea in healthy volunteers [65]. Interestingly, no severe side effects were reported during long-term administration (up to one year) of doses of up to $16 \mathrm{mg}$ grape RES [66]. Also, renal toxicity has been reported after a dose of $5 \mathrm{~g}$ RES in the form of SRT501 (developed by Sirtris, a GSK company) in two cycles during multiple myeloma, but no renal toxicity was observed in healthy controls, type 2 diabetics, or patients with mitochondrial encephalomyopathy, lactic acidosis, and stroke-like episodes (MELAS) syndrome [67]. The results suggest that the right dose of RES is essential to target specific diseases.

\subsection{Biological Effects of Resveratrol}

It has been shown that RES possesses numerous therapeutic effects, such as antioxidant [68-71], anti-inflammatory [72-75], cardioprotective [76-79], or analgesic effects [80-82], and has an impact 
on diabetes and obesity [83-85]. RES has been further studied for its increasing relevance in various neurological disorders, such as Alzheimer's [86-88], Parkinson's [89,90], and other neurodegenerative diseases [91,92], as well as brain tumors [93-95]. In addition, RES showed anticancer activity in many other cancer types, such as breast, prostate, skin, lung, liver, or colorectal cancer, as reviewed, for example, in [45,96-98].

\subsection{The Passing of Resveratrol through the Blood-Brain Barrier}

In 2002, Sinha et al. showed that RES exerts protective effects against oxidative stress in middle cerebral artery occlusion model stroke in rats [99]; however, they did not monitor the ability of RES to cross the blood-brain barrier (BBB). Nonetheless, during the same year, it was shown that RES crosses the BBB successfully and thus may protect against global cerebral ischemic injury [100]. One of the fundamental pathophysiology changes during ischemia reperfusion injury is the collapse of the BBB. RES at a dose of $50 \mathrm{mg} / \mathrm{kg}$ of body weight significantly decreased the infarct volume and improved the neurological score $24 \mathrm{~h}$ after reperfusion. Moreover, it improved the balance of matrix metalloproteinase-9 (MMP-9) and its endogenous inhibitor, TIMP-1. Thus, RES attenuated cerebral ischemia by maintaining the integrity of BBB via the regulation of MMP-9 and TIMP-1 [101]. At a lower dose of $20 \mathrm{mg} / \mathrm{kg}$ of body weight, RES reduced the cerebral infarct size, and improved BBB breakdown via the Hippo/YAP/TAZ pathway [102]. In another model of BBB dysfunction, autoimmune encephalomyelitis (EAE), RES at doses of 25 and $50 \mathrm{mg} / \mathrm{kg}$ of body weight was dose-dependently able to decrease EAE paralysis, ameliorate EAE-induced loss of tight junction proteins ZO-1, occludin, and claudin-5, and repress the EAE-induced increase in adhesion proteins ICAM-1 and VCAM-1 [103]. In addition, RES suppressed the EAE-induced overexpression of proinflammatory transcripts iNOS and IL-1 $\beta$ and upregulated the expression of anti-inflammatory transcripts arginase 1 and IL-10 cytokine in the brain, downregulated the overexpressed NOX2 and NOX4 in the brain, and suppressed NADPH activity [103]. However, the functional relationship between RES, BBB, brain cancer development, and antitumor therapy has not yet been determined (Figure 2).

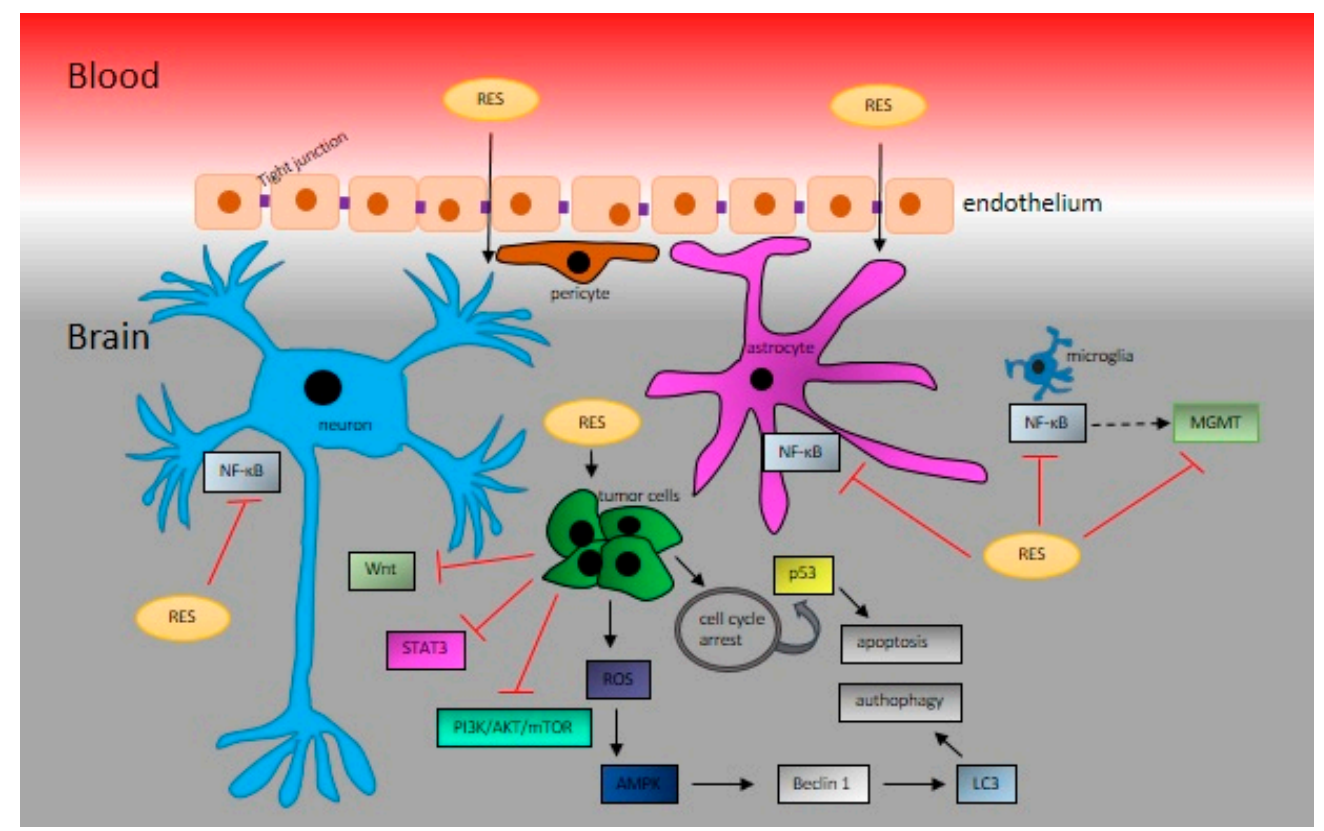

Figure 2. Resveratrol (RES) crosses the blood-brain barrier via tight junctions [104]. In the brain, RES inhibits NF-KB in neurons, astrocytes, and microglia. In brain cancer cells, RES exerts proapoptotic activities via influencing the cell cycle. RES induces oxidative stress, leading to autophagy. Moreover, RES influences cancer cells via various signaling mechanisms, including the PI3K/AKT/mTOR pathway, Wnt, or STAT3. 


\section{Resveratrol in Brain Cancer Studies}

In Europe, the incidence of primary CNS cancers ranges from 4.5 to 11.2 cases per 100,000 men and from 1.6 to 8.5 per 100,000 women. Astrocytic tumors include aggressive phenotype tumors such as glioblastoma (GBM). The five-year survival of primary brain cancers varied from $4.9 \%$ for high-grade to $43 \%$ for low-grade tumors [105]. GBM accounts for approximately $65 \%$ of all primary brain tumors and is characterized by low survival, with only $10 \%$ of patients surviving for five years [106]. GBM is one of the most malignant types of central nervous system tumors. Despite advances in treatment modalities, it remains largely incurable [107]. Gliomas account for almost $80 \%$ of all primary malignant brain tumors [108]. These include astrocytic tumors (astrocytoma, anaplastic astrocytoma and GBM), oligodendrogliomas, ependymomas, and mixed gliomas [109]. Despite the variety of modern therapies against GBM, it is still a deadly disease with extremely poor prognosis. Patients usually have a median survival of approximately 14 to 15 months from diagnosis [109,110].

The current gold standard in the treatment of GBM is temozolomide (TMZ)—an oral alkylating agent. TMZ is known to induce cell cycle arrest at G2/M, which leads to apoptosis. The cytotoxicity of TMZ is mediated by its addition of methyl groups at N7 and O6 sites on guanines and the O3 site on adenines in genomic DNA. Alkylation of the O6 site on guanine leads to the insertion of a thymine instead of a cytosine opposite the methylguanine during subsequent DNA replication, and this can result in cell death [111]. When TMZ is given concomitantly with radiotherapy, a statistically prolonged patient survival compared to TMZ-only therapy was shown ( $26.5 \%$ vs. $10.4 \%$ of the two-year survival rate). On the other hand, the concomitant treatment with radiotherapy plus TMZ resulted in grade 3 or 4 hematologic toxic effects in up to $10 \%$ of patients [112]. However, at least $50 \%$ of TMZ-treated patients do not respond to TMZ. This is due primarily to the overexpression of O6-methylguanine methyltransferase (MGMT) and/or a decreased rate of DNA repair in GBM cells $[111,113,114]$, involving a critical regulator of the 553 tumor suppressor, an MDM2 protein. MDM2 is overexpressed in many human malignancies. It inhibits DNA break repair [115]. Another mechanism of resistance of human gliomas causes ATP-binding cassette $(\mathrm{ABC})$ transporters to be overexpressed by the endothelial and/or epithelial cells of the BBB and the blood-tumor barrier [116].

One common feature in brain cancer types is the mutated form of isocitrate dehydrogenases (IDHs). NAD (+)-dependent IDHs in the mitochondria play a pivotal role in the production of NADH from $\mathrm{NAD}+$ in the Krebs cycle. As reviewed before, IDH mutations inhibit glioma stem cells' differentiation by producing high levels of 2-hydroxyglutaric acid (2-HG), regulate vascular endothelial growth factor (VEGF) to promote the formation of the tumor microenvironment, and induce high levels of hypoxia-inducible factor- $1 \alpha$ (HIF- $1 \alpha$ ) to promote glioma invasion [117]. IDH mutations also repress the tumor-associated immune system by inhibiting complement activation, while reducing the number of tumor-infiltrating T cells, phagocytosis and the excretion of cytokines. The oncometabolite 2-HG also affects epigenetics and genome stability. So, there are clinical trials being conducted on inhibitors of mutant IDH1, which target the production of 2-HG [118]. IDH1 mutations were predominantly found in human low-grade astrocytoma, oligodendroglioma, and secondary GBM. On the other hand, IDH2 mutations occurred less frequently in gliomas and were mutually exclusive of IDH1 mutations [119]. RES has been found to maintain IDH levels in a middle cerebral artery occlusion stroke model [120] and to protect the left ventricle by increasing IDH activity in myocardial infarction [121]. It has also been shown that RES stimulated a mitochondrial Complex I decrease in NADH concomitant with increased IDH levels in liver cells [122]. Even if many studies are dealing with the effect of RES on the Krebs cycle and mitochondrial enzymes, no study has described the direct potential of RES action on IDH during brain cancer.

\subsection{The Effect of Various Routes of Administration}

As described previously, RES has low bioavailability. However, the anticancer action of RES can be slightly modified by various routes of administration. Protection of RES from extensive metabolization in the gastrointestinal tract and liver increases its bioavailability [123], which is especially important 
in intracranial malignancies. RES administration via oral gavage or ad libitum in the water supply suppressed subcutaneous GBM xenograft growth in mice; intratumor or peritumor RES injection had a more pronounced effect on tumor volume [94]. RES administration via lumbar puncture effectively inhibited the growth of intracranial orthotopic rat GBM and prolonged the mean survival time of tumor-bearing animals [124]. Furthermore, a wide distribution of apoptotic foci with decreased Cyclin D1 staining, as well as enhanced autophagy with upregulated autophagy-related protein LC 3 and Beclin 1, was found after RES treatment in brain tumor tissue $[124,125]$. Lumbar puncture is even more effective than intra-arterial RES administration. Shu et al. [125] demonstrated a 5-fold higher concentration of RES in the whole brain after lumbar puncture compared to intra-arterial external carotid artery injection. Additionally, combination therapy such as lumbar-punctured RES with neurosurgery significantly improved the prognosis of rats with advanced orthotopic GBM, prolonged the postoperative survival time, suppressed tumor growth, induced apoptosis, and inactivated STAT3 signaling [126].

During brain cancer treatment, targeted RES delivery to the brain tumor tissue could help to overcome the low bioavailability, poor water solubility, and chemical instability of RES. To improve GBM treatment, various types of liposomes and polymeric nanoparticles were developed. Vijayakumar et al. [127] reported that the biological half-life, passive brain targeting, and antiglioma cytotoxicity of RES were significantly enhanced by using D- $\alpha$-tocopheryl polyethylene glycol 1000 succinate (TPGS)-coated liposomes (RES-TPGS-Lipo). Guo et al. [128] modified the surface of RES-loaded polyethylene glycol-polylactic acid nanoparticles with transferrin moieties (Tf-NP-RES), which led to increased intracellular uptake, higher cytotoxicity, and apoptosis of rat C6 and human U-87 MG GBM cell lines in vitro compared to free RES and nanoparticles without transferrin. Since transferrin receptors are exclusively expressed in brain capillaries [129], the accumulation of Tf-NP-RES in tumor tissue, decreased tumor volume, and prolonged survival were shown in rats bearing C6 orthotopic glioma. Similar results were obtained in the subcutaneous xenograft U-87 MG mouse model. Moreover, S-phase cell cycle arrest, activation of caspases 3/7, and higher production of reactive oxygen species were demonstrated in vitro [130]. Sallem et al. [131] have designed a new nanovector system for the delivery of a synthetic derivative of the RES molecule to the brain tissue, based on superparamagnetic iron oxide nanoparticles. This nanohybrid did not affect the mitochondrial metabolism, but damaged the plasma membrane of C6 glioma cells in vitro, indicating cytotoxic effects. The in vivo activity of this system still needs to be elucidated. Furthermore, the antitumor efficacy of RES-loaded nanoparticles may be enhanced by combination with other food-derived natural polyphenols, where synergistic effects are expected. Mukherjee et al. [132] have prepared liposomal TriCurin (TrLp; curcumin: epicatechin gallate: RES 4:1:12.5) and demonstrated that TrLp upregulates the activated protein $\mathrm{p} 53$ in cultured mouse GBM cells in vitro. Additionally, TrLp caused repolarization of M2-like tumor-associated microglia/macrophages to the tumoricidal M1-like phenotype, led the intratumoral recruitment of activated natural killer cells, suppressed tumor growth, and promoted the apoptosis of GBM and GBM stem cells in vivo [132]. Neves et al. [133] used solid lipid nanoparticles functionalized with apolipoprotein E, leading to increased (1.8-fold higher) permeability through the hCMED/D3 monolayer.

\subsection{Resveratrol and Standard Anticancer Therapy}

Numerous studies have shown that RES is able to alleviate the side effects induced by chemotherapeutic drugs [98,134]. Moreover, in combination with other anticancer agents, RES synergistically or additively enhances their efficacy against various types of cancer [135]. RES can reverse multidrug resistance and also can act as a sensitizer of cancer cells to standard chemotherapeutic drugs [97]. It has been demonstrated that RES increases TMZ efficacy through several mechanisms. TMZ induces both apoptosis and autophagy in human glioma cells through a reactive oxygen species (ROS) burst and extracellular signal-regulated kinase (ERK) activation. However, during these processes, autophagy protects glioma cells from apoptotic cell death. RES has been shown to augment the 
therapeutic capacity of TMZ by reducing ROS/ERK-mediated autophagy and subsequently increasing apoptosis both in vitro and in vivo [136]. In the human SHG44 GBM cell line, the combination RES+TMZ displayed additive antiproliferative effects by increased ROS production, subsequent activation of AMPK, inhibition of mTOR signaling, and downregulation of antiapoptotic protein Bcl-2. These results were confirmed in the orthotopic xenograft mouse model as the reduction of tumor volume and decreased expression of Ki-67, a marker of proliferation [137]. GBM-initiating cells (GICs) display stem cell properties and play a pivotal role in tumor development, resistance to TMZ, and tumor recurrence [138]. RES enhanced the sensitivity of these highly resistant cells to TMZ via activation of the DNA double strands/pATM/pATR/p53 pathway, leading to the activation of apoptosis. Additionally, RES promoted the differentiation of GIC involving p-STAT3 inactivation [139]. A RES dimer, $\varepsilon$-viniferin, has been shown to augment the apoptosis of the GBM cell line induced by another chemotherapeutic agent, cisplatin, under in vitro conditions through the activation of caspases 3,8 , and 9 [140].

RES also acts as a radiosensitizing anticancer agent in the prostate, skin, colon, breast cancer, hepatoma, leukemia, and others [141], including brain malignancies [142-144]. It has been demonstrated that RES is a radiation sensitizer for highly radioresistant human SU-2 glioma stem cells. The synergistic effect of RES and radiation was seen in the inhibition of cell proliferation, induction of autophagy, promotion of apoptosis, prevention of DNA repair in the early stage, and induction of differentiation, both in vitro and in vivo [145].

\subsection{Antiproliferative and Proapoptotic Effects of Resveratrol}

Antiproliferative, proapoptotic, and anti-inflammatory activities are considered to be the most important anticancer mechanisms of RES in different types of tumors [96,146,147]. Mammalian cell proliferation comprises two processes: (a) the cell cycle, including duplication of genetic material and cell division; (b) cell growth, regulated by many growth factors. The four phases of the cell cycle, i.e., G1 (Gap 1), S (synthesis), G2 (Gap 2), and M (mitosis), are mainly regulated by cyclin-dependent kinases (CDKs) that act in a complex with their cyclin partners [148]. Cell cycle arrest is an irreversible process that can result in apoptotic cell death [147]. RES was able to delay the cell cycle progression and inhibited the proliferation of rat C6 glioma cells by arresting the cell cycle at $S$ phase at micromolar concentrations [145]. The authors demonstrated the inhibition of the expression of specific oncogenic microRNAs (miRs) such as miR-21, miR-19, and miR-30a-5p in glioma cells, which was consequently associated with altered expression of their targeting genes such as p53, STAT3, EGFR, COX-2, NF- $\mathrm{B}$, and the PI3K/AKT/mTOR signaling pathway. Moreover, RES suppressed tumor growth and prolonged survival of rats bearing intracranial C6 glioma [145]. Induction of S-G2/M cell cycle arrest by RES was also described in human GBM cell lines and was accompanied by an increase in levels of pCdc2(Y15), cyclin A, E, and B and a decrease of cyclin D1 [149]. A recent investigation by Laaniste et al. [150] revealed that, in low-grade gliomas, the M2 gene-regulatory network, consisting of 177 genes and governing G2 to M progression, is substantially and significantly downregulated by RES. Transcription of late cell cycle genes such as FosM1 and B-Myb was the most affected, even at nanomolar RES concentrations [150].

Deregulation of precursor cell differentiation plays a crucial role in brain tumor development. Therefore, differentiation-promoting agents may potentially suppress GBM and medulloblastoma growth, reduce tumor resistance, and prevent recurrence in patients [151]. In human U87MG cells, RES induced glial-like and neuronal-like differentiation, as evidenced by decreased expression of nestin (stem cell marker) and, on the other hand, by increased expression of a glial acidic fibrillary protein (a mature glial cell marker) and of beta III-tubulin (a neuronal differentiation marker) in a time-dependent manner [152].

Some studies have indicated that RES also displays its anticancer activity on the level of posttranscriptional regulation of gene expression. Tristetraprolin (TTP) is an RNA binding protein that can bind AU-rich elements in target mRNAs with high affinity and then promote the deadenylation 
and decay of target transcripts such as proto-oncogenes, antiapoptotic genes, immune regulatory genes, and others [153,154]. In U87MG human glioma cells, RES increased TTP expression, thereby inducing apoptosis and suppressing cell growth [155].

\subsection{Resveratrol and Proteins of Resistance in Brain Cancer}

Though TMZ-based chemotherapy following neurosurgery has been proven to be effective, not all patients benefit clinically because of TMZ resistance. The most important feature of TMZ resistance is the expression of the protein MGMT [115]. It has been shown that RES reverses the TMZ-induced resistance of T98G GBM cells by downregulation of MGMT by the NF-kB-dependent pathway [156]. Repression of the activated Wnt signaling pathway through the downregulation of MGMT expression seems to be another way of inhibiting proliferation and facilitating the apoptosis of resistant glioma cells by the combination RES+TMZ [157]. The presence of RES forced various GBM cells (U87-MG, U-138 MG, and U251) treated with TMZ through mitosis leading to mitotic catastrophe and senescence, reducing the clonogenic capacity of cells and increasing the chronic effects of TMZ [158].

Another mechanism of resistance provide ABC transporters that are overexpressed in the $\mathrm{BBB}$ [116]. It has been previously reviewed that RES is able to reverse multidrug resistance via various mechanisms $[49,159]$. However, no study deals with this mechanism directly in brain cancer.

\subsection{Resveratrol and Cellular Senescence}

Cellular senescence is an irreversible cell cycle arrest that is considered to be an important tumor-suppressive mechanism as it stops proliferation. Therapy-induced senescence is thought to be an effective tool in cancer treatment, with fewer side effects than apoptosis-inducing treatment [160,161]. In a study with U87 and U118 human glioma cell lines, RES inhibited proliferation by inducing cellular senescence in a dose- and time-dependent manner [162]. RES induced significant changes in cell volume and cell morphology: spindle-shaped glioma cells were transformed to hypertrophic, flat cells expressing senescence-associated- $\beta$-galactosidase, a marker of senescence [161]. Moreover, RES inhibited the mono-ubiquitination of histone H2B at K120 (uH2B) [162]. Another study has shown that RES-induced senescence of human and rat glioma cells was increased by the inhibition of histone deacetylases [163]. The role of the histone deacetylase sirtuin 2 (SIRT2) as a mediator of the inhibitory action of RES on GBM stem cell (GSC) proliferation was revealed by Sayd et al. [164]. The blockade of the GSC cell cycle by RES at doses lesser than $150 \mu \mathrm{M}$ was mediated by SIRT2, whereas GSC necrosis induced by higher doses of RES was independent of sirtuin activity. Yang et al. [165] have shown that RES-induced glioma cell senescence, apoptosis, and antiproliferative effects could also be mediated by downregulation of POK erythroid myeloid ontogenic factor (Pokemon), at least partially through enhancement of the recruitment of histone deacetylase 1 (HDAC1) [165].

\subsection{Resveratrol and STAT3 Signaling}

Signal transducer and activator of transcription (STAT) 3 is a member of the family of transcription factors that is involved in the transmission of extracellular signals into the nucleus, thereby influencing the transcription of various genes. In carcinogenesis, STAT3 upregulates genes that can promote tumor survival, angiogenesis, resistance to cell death, and cell cycle progression [166]. Upregulation of STAT3 in GBM has been demonstrated in numerous studies, as reviewed by Kim et al. [167]. STAT3 is required for tumor formation and maintenance of the self-renewal of GBM stem-like cells [168,169], some of which express CD133 as a cancer stem cell marker [170]. It has been shown that RES displays its anticancer action on GBM-CD133+ tumor-initiating cells by inhibition of cell growth and viability, induction of apoptosis, suppression of self-renewal capacity, and enhancement of radiosensitivity in vitro and in vivo through the suppression of the STAT3 pathway [144]. Furthermore, in medulloblastoma, the most common type of primary brain malignancy in children [171], RES suppressed cell growth by STAT3 downregulation, decreased the incidence of STAT3 nuclear translocation, and promoted 
neuronal differentiation of medulloblastoma cells by axon regeneration and accumulation of SOCS3 to the synapse-like end of long cell processes [172].

\subsection{Resveratrol and $p 53$}

TP53 is a tumor suppressor protein commonly known as "a guardian of the genome". TP53 is one of the most commonly deregulated genes in various tumors, including GBM [173,174]. Suppression of p53 activity is associated with the activation of a serine/threonine protein kinase AKT, thereby promoting the survival and proliferation of tumor cells [175]. RES reduced AKT phosphorylation and induced p53 expression and subsequent transcription of downstream p53 target genes such as Bax, Pig8, and TP53INP in GBM cells. These changes led to the inhibition of cell growth and invasion of U87 glioma cells and glioma stem-like cells as well as the suppression of GBM mouse xenograft growth [94]. Moreover, in A172 and T98G GBM cell lines with a heterozygous p53 mutation, RES has been able to restore wild-type p53 expression via the activation of intracellular Notch-1 expression in a time-dependent manner. Simultaneous dephosphorylation of AKT, increased Bax expression, decreased Bcl-2 expression, and cleavage of caspase-3 were observed in this study, suggesting strong proapoptotic action of RES [176]. In a population of patient-derived glioma stem cells, which are responsible for tumor progression and poor patient prognosis, RES was found to reduce the self-renewal and tumor-initiating capacity of these cells via activation of the p53/p21 pathway and degradation of Nanog, a transcription factor essential for the retention of stemness [177].

\subsection{Resveratrol and Wnt Signaling}

As mentioned above, RES enhances the antiglioma efficacy of TMZ by inhibiting the Wnt signaling pathway, both in vitro and in vivo [157]. It has been demonstrated that the Wnt signal is essential for the self-renewal, migration, and differentiation of GBM stem cells [178]. The study of Cilibrasi et al. [93] revealed the highly heterogenous response of seven stem cell lines isolated from GBM-suffering patients to RES exposure. RES generally modulated the Wnt system, inhibited cell proliferation, increased cell mortality, and strongly decreased cell motility and invasiveness. As a result, suppression of nuclear $\beta$-catenin levels, increased transcription activity of Wnt target gene MYC, and a drastic decrease of c-Myc protein were observed. Additionally, RES inhibited epithelial-mesenchymal transition through downregulation of transcription factors Twist1 and Snail1 [93].

\section{Conclusions and Future Directions}

Resveratrol, a plant polyphenol occurring in nuts, berries, grapes, and red wine, demonstrates well-described anti-inflammatory, anti-oxidative, cardioprotective, and analgesic properties. Resveratrol is a molecule with very low toxicity that targets multiple molecular signaling pathways and consequently affects numerous carcinogenesis-related genes. The significant antineoplastic potential of resveratrol was demonstrated in many cancer types when administered alone or in combination with diverse anticancer agents and targeted therapies. It is known that resveratrol crosses the blood-brain barrier and influences the brain's structure. Its ability to prevent carcinogenesis in the brain includes the suppression of oxidative stress and inflammation, as well as inhibition of cell proliferation with the triggering of cell death mechanisms. It may influence cancer cells' activity via affecting various signaling mechanisms, including NF-kB, p53, Wnt, PI3K/AKT/mTOR, or STAT3. It has been described that resveratrol alleviates the resistance to standard alkylating agents, such as temozolomide, through influencing O6-methylguanine methyltransferase. However, the interaction between resveratrol and mutated isocitrate dehydrogenase, one of the key features of various brain cancer types, needs to be elucidated. Several other important questions must be resolved before the introduction of resveratrol into the clinical management of brain malignancies. To the best of our knowledge, no clinical trials have been conducted yet to evaluate the efficacy of resveratrol against brain cancer in humans. However, due to the number and complexity of cancer-related signaling pathways affected by resveratrol, further investigations are needed to overcome its pharmacokinetic limitations such as poor 
bioavailability in humans, describe its precise anticancer mechanisms of action, and define its efficacy in different brain cancer cell subtypes. With the intention to increase resveratrol's bioavailability in organisms and its potential as an adjuvant drug in clinical oncology, research should focus on resveratrol's delivery systems, formulations, dosing protocols, modulations of cancer cell metabolism, and possible interactions with other anticancer drugs. Finally, the development of optimized analogs of the resveratrol molecule to fit the specific mechanisms of anticancer action and increased stability and bioavailability in organisms should lead to its improved anticancer activity and reasonable clinical use.

\section{Data Search Strategy}

Data from the English-language biomedical literature were analyzed from the PubMed bibliographic database using terms such as "resveratrol", "brain cancer", "chemical properties", "metabolism", "bioavailability", "side effects", "blood-brain barrier", "glioblastoma", and "medulloblastoma" as a keyword or medical subject heading (MeSH) term. We focused on in vitro, in vivo, and clinical studies published from 2013 to 2020. As no clinical trials were found in PubMed, data were also reviewed from the U.S. National Institutes of Health database (http://www.clinicaltrials.gov/).

Author Contributions: Conceptualization, T.K. and M.K.; writing-original draft preparation, T.K. and M.K.; writing-review and editing, T.K., M.K., P.K., and D.B. All authors have read and agreed to the published version of the manuscript.

Funding: This work was supported by the Scientific Grant Agency of the Ministry of Education of the Slovak Republic under the contract no. VEGA 1/0658/20.

Conflicts of Interest: The authors declare no conflict of interest.

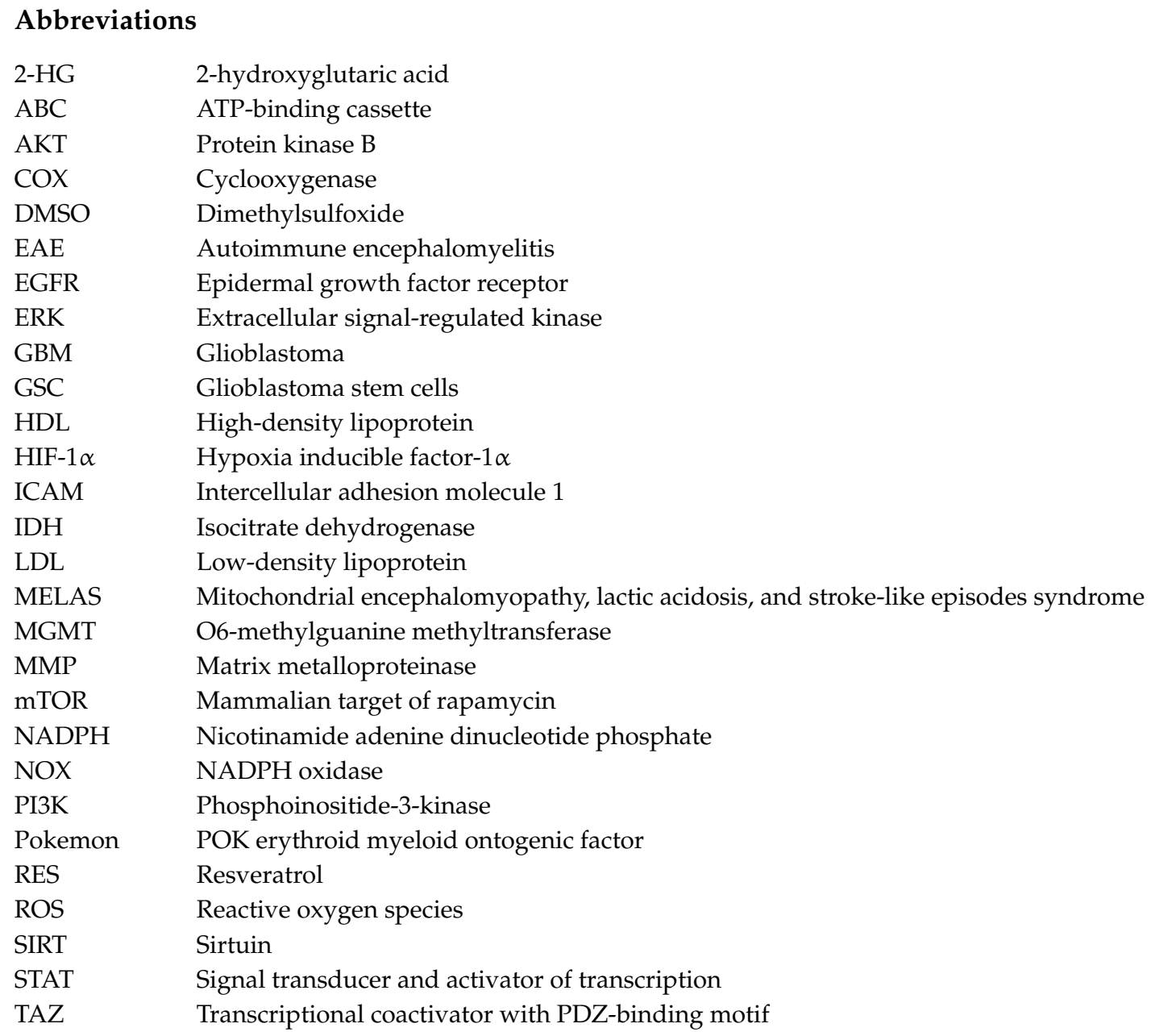




$\begin{array}{ll}\text { TIMP } & \text { Tissue inhibitor of metalloproteinases } \\ \text { TMZ } & \text { Temozolomide } \\ \text { TTP } & \text { Tristetraprolin } \\ \text { UGT } & \text { Uridine-diphosphate-glucuronosyltransferase } \\ \text { VCAM } & \text { Vascular cell adhesion molecule } \\ \text { VEGF } & \text { Vascular endothelial growth factor } \\ \text { VLDL } & \text { Very low-density lipoprotein } \\ \text { YAP } & \text { Yes-associated protein }\end{array}$

\section{References}

1. Shankar, S.; Singh, G.; Srivastava, R.K. Chemoprevention by resveratrol: Molecular mechanisms and therapeutic potential. Front. Biosci. 2007, 12, 4839-4854. [CrossRef] [PubMed]

2. Aggarwal, B.B.; Bhardwaj, A.; Aggarwal, R.S.; Seeram, N.P.; Shishodia, S.; Takada, Y. Role of resveratrol in prevention and therapy of cancer: Preclinical and clinical studies. Anticancer Res. 2004, 24, 2783-2840. [PubMed]

3. Armijo, G.; Schlechter, R.; Agurto, M.; Muñoz, D.; Nuñez, C.; Arce-Johnson, P. Grapevine Pathogenic Microorganisms: Understanding Infection Strategies and Host Response Scenarios. Front. Plant Sci. 2016, 7, 382. [CrossRef]

4. Hasan, M.; Bae, H. An Overview of Stress-Induced Resveratrol Synthesis in Grapes: Perspectives for Resveratrol-Enriched Grape Products. Molecules 2017, 22, 294. [CrossRef]

5. Donnez, D.; Jeandet, P.; Clement, C.; Courot, E. Bioproduction of resveratrol and stilbene derivatives by plant cells and microorganisms. Trends Biotechnol. 2009, 27, 706-713. [CrossRef]

6. Vannozzi, A.; Dry, I.B.; Fasoli, M.; Zenoni, S.; Lucchin, M. Genome-wide analysis of the grapevine stilbene synthase multigenic family: Genomic organization and expression profiles upon biotic and abiotic stresses. BMC Plant Biol. 2012, 12, 130. [CrossRef]

7. Vannozzi, A.; Wong, D.C.J.; Holl, J.; Hmmam, I.; Matus, J.T.; Bogs, J.; Ziegler, T.; Dry, I.; Barcaccia, G.; Lucchin, M. Combinatorial Regulation of Stilbene Synthase Genes by WRKY and MYB Transcription Factors in Grapevine (Vitis vinifera L.). Plant Cell Physiol. 2018, 59, 1043-1059. [CrossRef]

8. Takaoka, M. Resveratrol, a new phenolic compound, from Veratrum grandiflorum. Nippon Kagaku Kaishi 1939, 60, 1090-1100. [CrossRef]

9. Nonomura, X.; Kanawaga, X. Chemical constituents of Polygonaceous plants. I. Studies on the components of Ko-jo-kon. (Polygonum cuspidatum Sieb. et Zucc.). Yakugaku Zasshi 1963, 83, 988-990. [CrossRef]

10. Langcake, P.; Pryce, R.J. The production of resveratrol by Vitis vinifera and other members of the Vitaceae as a response to infection or injury. Physiol. Plant Pathol. 1976, 9, 77-86. [CrossRef]

11. Renaud, S.; de Lorgeril, M. Wine, alcohol, platelets, and the French paradox for coronary heart disease. Lancet (Lond. Engl.) 1992, 339, 1523-1526. [CrossRef]

12. Catalgol, B.; Batirel, S.; Taga, Y.; Ozer, N.K. Resveratrol: French paradox revisited. Front. Pharm. 2012, 3, 141. [CrossRef] [PubMed]

13. Ferrières, J. The French paradox: Lessons for other countries. Heart 2004, 90, 107-111. [CrossRef]

14. Nowbar, A.N.; Gitto, M.; Howard, J.P.; Francis, D.P.; Al-Lamee, R. Mortality from Ischemic Heart Disease. Circ. Cardiovasc. Qual. Outcomes 2019, 12, e005375. [CrossRef]

15. Siemann, E.H.; Creasy, L.L. Concentration of the Phytoalexin Resveratrol in Wine. Am. J. Enol. Vitic. 1992, 43, $49-52$.

16. Gronbaek, M.N.; Becker, P.U.; Johansen, D.; Gottschau, A.; Schnohr, P.; Hein, H.O.; Jensen, G.B.; Sorensen, T.I. Beer, wine, spirits and mortality. Results from a prospective population study. Ugeskr. Laeger. 2001, 163, 2946-2949.

17. Pandey, K.B.; Rizvi, S.I. Plant polyphenols as dietary antioxidants in human health and disease. Oxid. Med. Cell. Longev. 2009, 2, 270-278. [CrossRef]

18. Fraga, C.G.; Croft, K.D.; Kennedy, D.O.; Tomás-Barberán, F.A. The effects of polyphenols and other bioactives on human health. Food Funct. 2019, 10, 514-528. [CrossRef]

19. Salehi, B.; Mishra, A.P.; Nigam, M.; Sener, B.; Kilic, M.; Sharifi-Rad, M.; Fokou, P.V.T.; Martins, N.; Sharifi-Rad, J. Resveratrol: A Double-Edged Sword in Health Benefits. Biomedicines 2018, 6, 91. [CrossRef] 
20. Santos Sánchez, N.; Salas-Coronado, R.; Villanueva, C.; Hernandez-Carlos, B. Antioxidant Compounds and Their Antioxidant Mechanism. Antioxidants 2019. [CrossRef]

21. Zhang, H.; Tsao, R. Dietary polyphenols, oxidative stress and antioxidant and anti-inflammatory effects. Curr. Opin. Food Sci. 2016, 8, 33-42. [CrossRef]

22. Athar, M.; Back, J.H.; Tang, X.; Kim, K.H.; Kopelovich, L.; Bickers, D.R.; Kim, A.L. Resveratrol: A review of preclinical studies for human cancer prevention. Toxicol. Appl. Pharmacol. 2007, 224, 274-283. [CrossRef]

23. Camont, L.; Cottart, C.H.; Rhayem, Y.; Nivet-Antoine, V.; Djelidi, R.; Collin, F.; Beaudeux, J.L.; Bonnefont-Rousselot, D. Simple spectrophotometric assessment of the trans-/cis-resveratrol ratio in aqueous solutions. Anal. Chim. Acta 2009, 634, 121-128. [CrossRef] [PubMed]

24. Nour, V.; Trandafir, I.; Muntean, C. Ultraviolet Irradiation of Trans-Resveratrol and HPLC Determination of Trans-Resveratrol and Cis-Resveratrol in Romanian Red Wines. J. Chromatogr. Sci. 2012, 50, 920-927. [CrossRef] [PubMed]

25. Zupancic, S.; Lavric, Z.; Kristl, J. Stability and solubility of trans-resveratrol are strongly influenced by $\mathrm{pH}$ and temperature. Eur. J. Pharm. Biopharm. 2015, 93, 196-204. [CrossRef] [PubMed]

26. Francioso, A.; Mastromarino, P.; Masci, A.; d'Erme, M.; Mosca, L. Chemistry, stability and bioavailability of resveratrol. Med. Chem. 2014, 10, 237-245. [CrossRef]

27. Regev-Shoshani, G.; Shoseyov, O.; Bilkis, I.; Kerem, Z. Glycosylation of resveratrol protects it from enzymic oxidation. Biochem. J. 2003, 374, 157-163. [CrossRef]

28. Walle, T.; Hsieh, F.; DeLegge, M.H.; Oatis, J.E., Jr.; Walle, U.K. High absorption but very low bioavailability of oral resveratrol in humans. Drug Metab. Dispos. Biol. Fate Chem. 2004, 32, 1377-1382. [CrossRef]

29. Wang, P.; Sang, S. Metabolism and pharmacokinetics of resveratrol and pterostilbene. BioFactors 2018, 44, 16-25. [CrossRef]

30. Yu, C.; Shin, Y.G.; Chow, A.; Li, Y.; Kosmeder, J.W.; Lee, Y.S.; Hirschelman, W.H.; Pezzuto, J.M.; Mehta, R.G.; van Breemen, R.B. Human, rat, and mouse metabolism of resveratrol. Pharm. Res. 2002, 19, 1907-1914. [CrossRef]

31. Wang, D.; Hang, T.; Wu, C.; Liu, W. Identification of the major metabolites of resveratrol in rat urine by HPLC-MS/MS. J. Chromatogr. Banal. Technol. Biomed. Life Sci. 2005, 829, 97-106. [CrossRef] [PubMed]

32. Juan, M.E.; Alfaras, I.; Planas, J.M. Determination of dihydroresveratrol in rat plasma by HPLC. J. Agric. Food Chem. 2010, 58, 7472-7475. [CrossRef] [PubMed]

33. Jung, C.M.; Heinze, T.M.; Schnackenberg, L.K.; Mullis, L.B.; Elkins, S.A.; Elkins, C.A.; Steele, R.S.; Sutherland, J.B. Interaction of dietary resveratrol with animal-associated bacteria. FEMS Microbiol. Lett. 2009, 297, 266-273. [CrossRef] [PubMed]

34. Walle, T. Bioavailability of resveratrol. Ann. N. Y. Acad. Sci. 2011, 1215, 9-15. [CrossRef] [PubMed]

35. CN, N.s.-K.; St-Louis, C.; Beauregard, M.; Subirade, M.; Carpentier, R.; Hotchandani, S.; Tajmir-Riahi, H.A. Resveratrol binding to human serum albumin. J. Biomol. Struct. Dyn. 2006, 24, 277-283. [CrossRef]

36. Jannin, B.; Menzel, M.; Berlot, J.P.; Delmas, D.; Lancon, A.; Latruffe, N. Transport of resveratrol, a cancer chemopreventive agent, to cellular targets: Plasmatic protein binding and cell uptake. Biochem. Pharmacol. 2004, 68, 1113-1118. [CrossRef]

37. Frombaum, M.; Le Clanche, S.; Therond, P.; Nubret, E.; Bonnefont-Rousselot, D.; Borderie, D. Penetration of resveratrol into bovine aortic endothelial cells (BAEC): A possible passive diffusion. C. R. Biol. 2012, 335, 247-252. [CrossRef]

38. Gojkovic-Bukarica, L.; Novakovic, A.; Kanjuh, V.; Bumbasirevic, M.; Lesic, A.; Heinle, H. A role of ion channels in the endothelium-independent relaxation of rat mesenteric artery induced by resveratrol. J. Pharmacol. Sci. 2008, 108, 124-130. [CrossRef]

39. Chen, M.L.; Yi, L.; Jin, X.; Xie, Q.; Zhang, T.; Zhou, X.; Chang, H.; Fu, Y.J.; Zhu, J.D.; Zhang, Q.Y.; et al. Absorption of resveratrol by vascular endothelial cells through passive diffusion and an SGLT1-mediated pathway. J. Nutr. Biochem. 2013, 24, 1823-1829. [CrossRef]

40. Lancon, A.; Delmas, D.; Osman, H.; Thenot, J.P.; Jannin, B.; Latruffe, N. Human hepatic cell uptake of resveratrol: Involvement of both passive diffusion and carrier-mediated process. Biochem. Biophys. Res. Commun. 2004, 316, 1132-1137. [CrossRef]

41. Soleas, G.J.; Angelini, M.; Grass, L.; Diamandis, E.P.; Goldberg, D.M. Absorption of trans-resveratrol in rats. Methods Enzymol. 2001, 335, 145-154. [CrossRef] [PubMed] 
42. Vitrac, X.; Desmouliere, A.; Brouillaud, B.; Krisa, S.; Deffieux, G.; Barthe, N.; Rosenbaum, J.; Merillon, J.M. Distribution of $\left[{ }^{14} \mathrm{C}\right]$-trans-resveratrol, a cancer chemopreventive polyphenol, in mouse tissues after oral administration. Life Sci. 2003, 72, 2219-2233. [CrossRef]

43. Böhmdorfer, M.; Szakmary, A.; Schiestl, R.H.; Vaquero, J.; Riha, J.; Brenner, S.; Thalhammer, T.; Szekeres, T.; Jäger, W. Involvement of UDP-Glucuronosyltransferases and Sulfotransferases in the Excretion and Tissue Distribution of Resveratrol in Mice. Nutrients 2017, 9, 1347. [CrossRef]

44. Chaplin, A.; Carpene, C.; Mercader, J. Resveratrol, Metabolic Syndrome, and Gut Microbiota. Nutrients 2018, 10, 1651. [CrossRef]

45. Kisková, T.; Kassayová, M. Resveratrol Action on Lipid Metabolism in Cancer. Int. J. Mol. Sci. 2019, $20,2704$. [CrossRef]

46. Berman, A.Y.; Motechin, R.A.; Wiesenfeld, M.Y.; Holz, M.K. The therapeutic potential of resveratrol: A review of clinical trials. Npj Precis Oncol. 2017, 1, 35. [CrossRef]

47. Kiskova, T.; Demeckova, V.; Jendzelovska, Z.; Kiktava, M.; Venglovska, K.; Bohmdorfer, M.; Jager, W.; Thalhammer, T. Nocturnal resveratrol administration inhibits chemically induced breast cancer formation in rats. J. Physiol. Pharmacol. 2017, 68, 867-875.

48. Kiskova, T.; Jendzelovsky, R.; Rentsen, E.; Maier-Salamon, A.; Kokosova, N.; Papcova, Z.; Mikes, J.; Orendas, P.; Bojkova, B.; Kubatka, P.; et al. Resveratrol enhances the chemopreventive effect of celecoxib in chemically induced breast cancer in rats. Eur. J. Cancer Prev. 2014, 23, 506-513. [CrossRef]

49. Aires, V.; Colin, D.J.; Doreau, A.; Di Pietro, A.; Heydel, J.-M.; Artur, Y.; Latruffe, N.; Delmas, D. P-Glycoprotein 1 Affects Chemoactivities of Resveratrol against Human Colorectal Cancer Cells. Nutrients 2019, 11, 2098. [CrossRef]

50. Colin, D.; Gimazane, A.; Lizard, G.; Izard, J.-C.; Solary, E.; Latruffe, N.; Delmas, D. Effects of resveratrol analogs on cell cycle progression, cell cycle associated proteins and 5-fluoro-uracil sensitivity in human derived colon cancer cells. Int. J. Cancer 2009, 124, 2780-2788. [CrossRef]

51. Colin, D.; Limagne, E.; Jeanningros, S.; Jacquel, A.; Lizard, G.; Athias, A.; Gambert, P.; Hichami, A.; Latruffe, N.; Solary, E.; et al. Endocytosis of resveratrol via lipid rafts and activation of downstream signaling pathways in cancer cells. Cancer Prev. Res. 2011, 4, 1095-1106. [CrossRef] [PubMed]

52. Bresciani, L.; Calani, L.; Bocchi, L.; Delucchi, F.; Savi, M.; Ray, S.; Brighenti, F.; Stilli, D.; Del Rio, D. Bioaccumulation of resveratrol metabolites in myocardial tissue is dose-time dependent and related to cardiac hemodynamics in diabetic rats. Nutr. Metab. Cardiovasc. Dis. NMCD 2014, 24, 408-415. [CrossRef]

53. Wang, S.; Wang, Z.; Yang, S.; Yin, T.; Zhang, Y.; Qin, Y.; Weinreb, R.; Sun, X. Tissue Distribution of trans -Resveratrol and Its Metabolites after Oral Administration in Human Eyes. J. Ophthalmol. 2017, 2017, 1-12. [CrossRef]

54. van Ginkel, P.R.; Sareen, D.; Subramanian, L.; Walker, Q.; Darjatmoko, S.R.; Lindstrom, M.J.; Kulkarni, A.; Albert, D.M.; Polans, A.S. Resveratrol inhibits tumor growth of human neuroblastoma and mediates apoptosis by directly targeting mitochondria. Clin. Cancer Res. 2007, 13, 5162-5169. [CrossRef] [PubMed]

55. Almeida, L.; Vaz-da-Silva, M.; Falcao, A.; Soares, E.; Costa, R.; Loureiro, A.I.; Fernandes-Lopes, C.; Rocha, J.F.; Nunes, T.; Wright, L.; et al. Pharmacokinetic and safety profile of trans-resveratrol in a rising multiple-dose study in healthy volunteers. Mol. Nutr. Food Res. 2009, 53 (Suppl. 1), S7-S15. [CrossRef]

56. Cottart, C.H.; Nivet-Antoine, V.; Laguillier-Morizot, C.; Beaudeux, J.L. Resveratrol bioavailability and toxicity in humans. Mol. Nutr. Food Res. 2010, 54, 7-16. [CrossRef]

57. Sergides, C.; Chirilă, M.; Silvestro, L.; Pitta, D.; Pittas, A. Bioavailability and safety study of resveratrol 500 mg tablets in healthy male and female volunteers. Exp. Med. 2016, 11, 164-170. [CrossRef]

58. Peñalva, R.; Morales, J.; González-Navarro, C.J.; Larrañeta, E.; Quincoces, G.; Peñuelas, I.; Irache, J.M. Increased Oral Bioavailability of Resveratrol by Its Encapsulation in Casein Nanoparticles. Int. J. Mol. Sci. 2018, 19, 2816. [CrossRef]

59. Chimento, A.; De Amicis, F.; Sirianni, R.; Sinicropi, M.S.; Puoci, F.; Casaburi, I.; Saturnino, C.; Pezzi, V. Progress to Improve Oral Bioavailability and Beneficial Effects of Resveratrol. Int. J. Mol. Sci. 2019, 20, 1381. [CrossRef]

60. de Vries, K.; Strydom, M.; Steenkamp, V. Bioavailability of resveratrol: Possibilities for enhancement. J. Herb. Med. 2018, 11, 71-77. [CrossRef] 
61. Calvo-Castro, L.A.; Schiborr, C.; David, F.; Ehrt, H.; Voggel, J.; Sus, N.; Behnam, D.; Bosy-Westphal, A.; Frank, J. The Oral Bioavailability of Trans-Resveratrol from a Grapevine-Shoot Extract in Healthy Humans is Significantly Increased by Micellar Solubilization. Mol. Nutr. Food Res. 2018, 62. [CrossRef] [PubMed]

62. Bojanowski, K.; Bojanowski, R. Two Methods of Oral Delivery of Resveratrol: A case study. J. Aging Res. Clin. Pract. 2015, 4, 185-189. [CrossRef]

63. Patel, K.R.; Scott, E.; Brown, V.A.; Gescher, A.J.; Steward, W.P.; Brown, K. Clinical trials of resveratrol. Ann. N. Y. Acad. Sci. 2011, 1215, 161-169. [CrossRef] [PubMed]

64. Singh, C.K.; Ndiaye, M.A.; Ahmad, N. Resveratrol and cancer: Challenges for clinical translation. Biochim. Biophys. Acta 2015, 1852, 1178-1185. [CrossRef] [PubMed]

65. Brown, V.A.; Patel, K.R.; Viskaduraki, M.; Crowell, J.A.; Perloff, M.; Booth, T.D.; Vasilinin, G.; Sen, A.; Schinas, A.M.; Piccirilli, G.; et al. Repeat dose study of the cancer chemopreventive agent resveratrol in healthy volunteers: Safety, pharmacokinetics, and effect on the insulin-like growth factor axis. Cancer Res. 2010, 70, 9003-9011. [CrossRef]

66. Tome-Carneiro, J.; Gonzalvez, M.; Larrosa, M.; Yanez-Gascon, M.J.; Garcia-Almagro, F.J.; Ruiz-Ros, J.A.; Tomas-Barberan, F.A.; Garcia-Conesa, M.T.; Espin, J.C. Grape resveratrol increases serum adiponectin and downregulates inflammatory genes in peripheral blood mononuclear cells: A triple-blind, placebo-controlled, one-year clinical trial in patients with stable coronary artery disease. Cardiovasc. Drugs Ther. 2013, 27, 37-48. [CrossRef]

67. Popat, R.; Plesner, T.; Davies, F.; Cook, G.; Cook, M.; Elliott, P.; Jacobson, E.; Gumbleton, T.; Oakervee, H.; Cavenagh, J. A phase 2 study of SRT501 (resveratrol) with bortezomib for patients with relapsed and or refractory multiple myeloma. Br. J. Haematol. 2013, 160, 714-717. [CrossRef]

68. Gerszon, J.; Rodacka, A.; Puchała, M. Antioxidant Properties of Resveratrol and its Protective Effects in Neurodegenerative Diseases. Adv. Cell Biol. 2014, 4, 97. [CrossRef]

69. Gülçin, İ. Antioxidant properties of resveratrol: A structure-activity insight. Innov. Food Sci. Emerg. Technol. 2010, 11, 210-218. [CrossRef]

70. Kong, D.; Yan, Y.; He, X.-Y.; Yang, H.; Liang, B.; Wang, J.; He, Y.; Ding, Y.; Yu, H. Effects of Resveratrol on the Mechanisms of Antioxidants and Estrogen in Alzheimer's Disease. Biomed. Res. Int. 2019, 2019, 8. [CrossRef]

71. Xia, N.; Daiber, A.; Forstermann, U.; Li, H. Antioxidant effects of resveratrol in the cardiovascular system. Br. J. Pharmacol. 2017, 174, 1633-1646. [CrossRef]

72. de Sá Coutinho, D.; Pacheco, M.T.; Frozza, R.L.; Bernardi, A. Anti-Inflammatory Effects of Resveratrol: Mechanistic Insights. Int. J. Mol. Sci. 2018, 19, 1812. [CrossRef]

73. El-Ghazaly, M.A.; Fadel, N.A.; Abdel-Naby, D.H.; Abd El-Rehim, H.A.; Zaki, H.F.; Kenawy, S.A. Potential anti-inflammatory action of resveratrol and piperine in adjuvant-induced arthritis: Effect on pro-inflammatory cytokines and oxidative stress biomarkers. Egypt. Rheumatol. 2019. [CrossRef]

74. Liu, F.-C.; Tsai, Y.-F.; Tsai, H.-I.; Yu, H.-P. Anti-Inflammatory and Organ-Protective Effects of Resveratrol in Trauma-Hemorrhagic Injury. Mediat. Inflamm. 2015, 9. [CrossRef]

75. Lomholt, S.; Mellemkjaer, A.; Iversen, M.B.; Pedersen, S.B.; Kragstrup, T.W. Resveratrol displays anti-inflammatory properties in an ex vivo model of immune mediated inflammatory arthritis. BMC Rheumatol. 2018, 2, 27. [CrossRef] [PubMed]

76. Magyar, K.; Halmosi, R.; Palfi, A.; Feher, G.; Czopf, L.; Fulop, A.; Battyany, I.; Sumegi, B.; Toth, K.; Szabados, E. Cardioprotection by resveratrol: A human clinical trial in patients with stable coronary artery disease. Clin. Hemorheol. Microcirc. 2012, 50, 179-187. [CrossRef] [PubMed]

77. Riba, A.; Deres, L.; Sumegi, B.; Toth, K.; Szabados, E.; Halmosi, R. Cardioprotective Effect of Resveratrol in a Postinfarction Heart Failure Model. Oxid. Med. Cell Longev. 2017, 2017, 6819281. [CrossRef] [PubMed]

78. Wu, J.M.; Hsieh, T.C. Resveratrol: A cardioprotective substance. Ann. N. Y. Acad. Sci. 2011, 1215, 16-21. [CrossRef]

79. Wu, J.M.; Hsieh, T.-C.; Wang, Z. Cardioprotection by resveratrol: A review of effects/targets in cultured cells and animal tissues. Am. J. Cardiovasc. Dis. 2011, 1, 38-47.

80. Bazzo, K.O.; Souto, A.A.; Lopes, T.G.; Zanin, R.F.; Gomez, M.V.; Souza, A.H.; Campos, M.M. Evidence for the analgesic activity of resveratrol in acute models of nociception in mice. J. Nat. Prod. 2013, 76, 13-21. [CrossRef]

81. Bertelli, A.; Falchi, M.; Dib, B.; Pini, E.; Mukherjee, S.; Das, D.K. Analgesic resveratrol? Antioxid. Redox Signal. 2008, 10, 403-404. [CrossRef] [PubMed] 
82. Ogboli Nwasor, E.; Isa, A.-S.; Dingwoke, E.; Umar, A. Analgesic and anti-inflammatory effects of resveratrol in rat models of pain: Any role in clinical pain management? Arch. Med. Surg. 2018, 3, 19-23. [CrossRef]

83. Oyenihi, O.R.; Oyenihi, A.B.; Adeyanju, A.A.; Oguntibeju, O.O. Antidiabetic Effects of Resveratrol: The Way Forward in Its Clinical Utility. J. Diabetes Res. 2016, 2016, 9737483. [CrossRef] [PubMed]

84. Szkudelski, T.; Szkudelska, K. Anti-diabetic effects of resveratrol. Ann. N. Y. Acad. Sci. 2011, 1215, 34-39. [CrossRef]

85. Thadhani, V. Resveratrol in Management of Diabetes and Obesity: Clinical Applications, Bioavailability, and Nanotherapy. In Resveratrol-Adding Life to Years, Not Adding Years to Life; IntechOpen: Rijeka, Croatia, 2019. [CrossRef]

86. Gomes, B.A.Q.; Silva, J.P.B.; Romeiro, C.F.R.; dos Santos, S.M.; Rodrigues, C.A.; Gonçalves, P.R.; et al. Neuroprotective Mechanisms of Resveratrol in Alzheimer's Disease: Role of SIRT1. Oxid. Med. Cell Longev. 2018, 2018, 15. [CrossRef]

87. Martin, I. Resveratrol for Alzheimer's disease? Sci. Transl. Med. 2017, 9. [CrossRef]

88. Sawda, C.; Moussa, C.; Turner, R.S. Resveratrol for Alzheimer's disease. Ann. N. Y. Acad. Sci. 2017, 1403, 142-149. [CrossRef]

89. Ferretta, A.; Gaballo, A.; Tanzarella, P.; Piccoli, C.; Capitanio, N.; Nico, B.; Annese, T.; Di Paola, M.; Dell'aquila, C.; De Mari, M.; et al. Effect of resveratrol on mitochondrial function: Implications in parkin-associated familiar Parkinson's disease. Biochim. Biophys. Acta 2014, 1842, 902-915. [CrossRef]

90. Xia, D.; Sui, R.; Zhang, Z. Administration of resveratrol improved Parkinson's disease-like phenotype by suppressing apoptosis of neurons via modulating the MALAT1/miR-129/SNCA signaling pathway. J. Cell. Biochem. 2019, 120, 4942-4951. [CrossRef]

91. Andrade, S.; Ramalho, M.J.; Pereira, M.D.C.; Loureiro, J.A. Resveratrol Brain Delivery for Neurological Disorders Prevention and Treatment. Front. Pharm. 2018, 9, 1261. [CrossRef]

92. Tellone, E.; Galtieri, A.; Russo, A.; Giardina, B.; Ficarra, S. Resveratrol: A Focus on Several Neurodegenerative Diseases. Oxid. Med. Cell Longev. 2015, 2015, 392169. [CrossRef] [PubMed]

93. Cilibrasi, C.; Riva, G.; Romano, G.; Cadamuro, M.; Bazzoni, R.; Butta, V.; Paoletta, L.; Dalprà, L.; Strazzabosco, M.; Lavitrano, M.; et al. Resveratrol Impairs Glioma Stem Cells Proliferation and Motility by Modulating the Wnt Signaling Pathway. PLoS ONE 2017, 12, e0169854. [CrossRef] [PubMed]

94. Clark, P.A.; Bhattacharya, S.; Elmayan, A.; Darjatmoko, S.R.; Thuro, B.A.; Yan, M.B.; van Ginkel, P.R.; Polans, A.S.; Kuo, J.S. Resveratrol targeting of AKT and p53 in glioblastoma and glioblastoma stem-like cells to suppress growth and infiltration. J. Neurosurg. 2017, 126, 1448-1460. [CrossRef] [PubMed]

95. Öztürk, Y.; Günaydın, C.; Yalçın, F.; Nazıroğlu, M.; Braidy, N. Resveratrol Enhances Apoptotic and Oxidant Effects of Paclitaxel through TRPM2 Channel Activation in DBTRG Glioblastoma Cells. Oxid. Med. Cell Longev. 2019, 13. [CrossRef]

96. Honari, M.; Shafabakhsh, R.; Reiter, R.J.; Mirzaei, H.; Asemi, Z. Resveratrol is a promising agent for colorectal cancer prevention and treatment: Focus on molecular mechanisms. Cancer Cell Int. 2019, 180. [CrossRef]

97. Ko, J.-H.; Sethi, G.; Um, J.-Y.; Shanmugam, M.K.; Arfuso, F.; Kumar, A.P.; Bishayee, A.; Ahn, K.S. The Role of Resveratrol in Cancer Therapy. Int. J. Mol. Sci. 2017, 18, 2589. [CrossRef]

98. Xiao, Q.; Zhu, W.; Feng, W.; Lee, S.S.; Leung, A.W.; Shen, J.; Gao, L.; Xu, C. A Review of Resveratrol as a Potent Chemoprotective and Synergistic Agent in Cancer Chemotherapy. Front. Pharm. 2019, 9. [CrossRef]

99. Sinha, K.; Chaudhary, G.; Kumar Gupta, Y. Protective effect of resveratrol against oxidative stress in middle cerebral artery occlusion model of stroke in rats. Life Sci. 2002, 71, 655-665. [CrossRef]

100. Wang, Q.; Xu, J.; Rottinghaus, G.E.; Simonyi, A.; Lubahn, D.; Sun, G.Y.; Sun, A.Y. Resveratrol protects against global cerebral ischemic injury in gerbils. Brain Res. 2002, 958, 439-447. [CrossRef]

101. Wei, H.; Wang, S.; Zhen, L.; Yang, Q.; Wu, Z.; Lei, X.; Lv, J.; Xiong, L.; Xue, R. Resveratrol Attenuates the Blood-Brain Barrier Dysfunction by Regulation of the MMP-9/TIMP-1 Balance after Cerebral Ischemia Reperfusion in Rats. J. Mol. Neurosci. 2015, 55, 872-879. [CrossRef]

102. Ganji, H.; Ying, Y.; Yali, Z.; Jianer, C.; Fei, T.; Qilin, M. Combined Ischemic Preconditioning and Resveratrol Improved Bloodbrain Barrier Breakdown via Hippo/YAP/TAZ Signaling Pathway. CNS Neurol. Disord.—Drug Targets 2019, 18, 713-722. [CrossRef]

103. Wang, D.; Li, S.-P.; Fu, J.-S.; Zhang, S.; Bai, L.; Guo, L. Resveratrol defends blood-brain barrier integrity in experimental autoimmune encephalomyelitis mice. J. Neurophysiol. 2016, 116, 2173-2179. [CrossRef] [PubMed] 
104. Crocetti, E.; Trama, A.; Stiller, C.; Caldarella, A.; Soffietti, R.; Jaal, J.; Weber, D.C.; Ricardi, U.; Slowinski, J.; Brandes, A. Epidemiology of glial and non-glial brain tumours in Europe. Eur. J. Cancer 2012, 48, 1532-1542. [CrossRef]

105. Ellis, H.P.; Greenslade, M.; Powell, B.; Spiteri, I.; Sottoriva, A.; Kurian, K.M. Current Challenges in Glioblastoma: Intratumour Heterogeneity, Residual Disease, and Models to Predict Disease Recurrence. Front. Oncol. 2015, 5. [CrossRef]

106. Hanif, F.; Muzaffar, K.; Perveen, K.; Malhi, S.M.; Simjee, S.U. Glioblastoma Multiforme: A Review of its Epidemiology and Pathogenesis through Clinical Presentation and Treatment. Asian Pac. J. Cancer Prev. 2017, 18, 3-9. [CrossRef] [PubMed]

107. Minniti, G.; Lombardi, G.; Paolini, S. Glioblastoma in Elderly Patients: Current Management and Future Perspectives. Cancers 2019, 11, 336. [CrossRef] [PubMed]

108. Agnihotri, S.; Burrell, K.E.; Wolf, A.; Jalali, S.; Hawkins, C.; Rutka, J.T.; Zadeh, G. Glioblastoma, a brief review of history, molecular genetics, animal models and novel therapeutic strategies. Arch. Immunol. Ther. Exp. 2013, 61, 25-41. [CrossRef] [PubMed]

109. Thakkar, J.P.; Dolecek, T.A.; Horbinski, C.; Ostrom, Q.T.; Lightner, D.D.; Barnholtz-Sloan, J.S.; Villano, J.L. Epidemiologic and molecular prognostic review of glioblastoma. Cancer Epidemiol. Biomark. Prev. 2014, 23, 1985-1996. [CrossRef]

110. Lee, S.Y. Temozolomide resistance in glioblastoma multiforme. Genes Dis. 2016, 3, 198-210. [CrossRef]

111. Stupp, R.; Mason, W.P.; van den Bent, M.J.; Weller, M.; Fisher, B.; Taphoorn, M.J.; Belanger, K.; Brandes, A.A.; Marosi, C.; Bogdahn, U.; et al. Radiotherapy plus concomitant and adjuvant temozolomide for glioblastoma. N. Engl. J. Med. 2005, 352, 987-996. [CrossRef]

112. Jiapaer, S.; Furuta, T.; Tanaka, S.; Kitabayashi, T.; Nakada, M. Potential Strategies Overcoming the Temozolomide Resistance for Glioblastoma. Neurol Med. Chir. 2018, 58, 405-421. [CrossRef] [PubMed]

113. Yi, G.-Z.; Huang, G.; Guo, M.; Zhang, X.A.; Wang, H.; Deng, S.; Li, Y.; Xiang, W.; Chen, Z.; Pan, J.; et al. Acquired temozolomide resistance in MGMT-deficient glioblastoma cells is associated with regulation of DNA repair by DHC2. Brain 2019, 142, 2352-2366. [CrossRef] [PubMed]

114. Eischen, C.M. Role of Mdm2 and Mdmx in DNA repair. J. Mol. Cell Biol. 2017, 9, 69-73. [CrossRef] [PubMed]

115. Decleves, X.; Amiel, A.; Delattre, J.Y.; Scherrmann, J.M. Role of ABC transporters in the chemoresistance of human gliomas. Curr. Cancer Drug Targets 2006, 6, 433-445. [CrossRef] [PubMed]

116. Huang, J.; Yu, J.; Tu, L.; Huang, N.; Li, H.; Luo, Y. Isocitrate Dehydrogenase Mutations in Glioma: From Basic Discovery to Therapeutics Development. Front. Oncol. 2019, 9, 506. [CrossRef] [PubMed]

117. Bhavya, B.; Anand, C.R.; Madhusoodanan, U.K.; Rajalakshmi, P.; Krishnakumar, K.; Easwer, H.V.; Deepti, A.N.; Gopala, S. To be Wild or Mutant: Role of Isocitrate Dehydrogenase 1 (IDH1) and 2-Hydroxy Glutarate (2-HG) in Gliomagenesis and Treatment Outcome in Glioma. Cell. Mol. Neurobiol. 2020, 40, 53-63. [CrossRef]

118. Guo, C.; Pirozzi, C.J.; Lopez, G.Y.; Yan, H. Isocitrate dehydrogenase mutations in gliomas: Mechanisms, biomarkers and therapeutic target. Curr. Opin. Neurol. 2011, 24, 648-652. [CrossRef]

119. Shah, F.-A.; Gim, S.-A.; Kim, M.-O.; Koh, P.-O. Proteomic identification of proteins differentially expressed in response to resveratrol treatment in middle cerebral artery occlusion stroke model. J. Vet. Med. Sci. 2014, 76, 1367-1374. [CrossRef]

120. Lin, J.F.; Wu, S.; Huang, S.S.; Lu, B.Y.; Lin, S.M.; Tsai, S.K. Resveratrol protects left ventricle by increasing adenylate kinase and isocitrate dehydrogenase activities in rats with myocardial infarction. Chin. J. Physiol. 2011, 54, 406-412. [CrossRef]

121. Desquiret-Dumas, V.; Gueguen, N.; Leman, G.; Baron, S.; Nivet-Antoine, V.; Chupin, S.; Chevrollier, A.; Vessieres, E.; Ayer, A.; Ferre, M.; et al. Resveratrol induces a mitochondrial complex I-dependent increase in NADH oxidation responsible for sirtuin activation in liver cells. J. Biol. Chem. 2013, 288, 36662-36675. [CrossRef]

122. Smoliga, J.M.; Blanchard, O. Enhancing the delivery of resveratrol in humans: If low bioavailability is the problem, what is the solution? Molecules 2014, 19, 17154-17172. [CrossRef] [PubMed]

123. Xue, S.; Xiao-Hong, S.; Lin, S.; Jie, B.; Li-Li, W.; Jia-Yao, G.; Shun, S.; Pei-Nan, L.; Mo-Li, W.; Qian, W.; et al. Lumbar puncture-administered resveratrol inhibits STAT3 activation, enhancing autophagy and apoptosis in orthotopic rat glioblastomas. Oncotarget 2016, 7, 75790-75799. [CrossRef] [PubMed] 
124. Shu, X.H.; Wang, L.L.; Li, H.; Song, X.; Shi, S.; Gu, J.Y.; Wu, M.L.; Chen, X.Y.; Kong, Q.Y.; Liu, J. Diffusion Efficiency and Bioavailability of Resveratrol Administered to Rat Brain by Different Routes: Therapeutic Implications. Neurother. J. Am. Soc. Exp. Neurother. 2015, 12, 491-501. [CrossRef] [PubMed]

125. Song, X.; Shu, X.-H.; Wu, M.-L.; Zheng, X.; Jia, B.; Kong, Q.-Y.; Liu, J.; Li, H. Postoperative resveratrol administration improves prognosis of rat orthotopic glioblastomas. BMC Cancer 2018, 18, 871. [CrossRef]

126. Vijayakumar, M.R.; Vajanthri, K.Y.; Balavigneswaran, C.K.; Mahto, S.K.; Mishra, N.; Muthu, M.S.; Singh, S. Pharmacokinetics, biodistribution, in vitro cytotoxicity and biocompatibility of Vitamin E TPGS coated trans resveratrol liposomes. Colloids Surf. Bbiointerfaces 2016, 145, 479-491. [CrossRef] [PubMed]

127. Guo, W.; Li, A.; Jia, Z.; Yuan, Y.; Dai, H.; Li, H. Transferrin modified PEG-PLA-resveratrol conjugates: In vitro and in vivo studies for glioma. Eur. J. Pharmacol. 2013, 718, 41-47. [CrossRef]

128. Johnsen, K.B.; Burkhart, A.; Melander, F.; Kempen, P.J. Targeting transferrin receptors at the blood-brain barrier improves the uptake of immunoliposomes and subsequent cargo transport into the brain parenchyma. Sci. Rep. 2017, 7, 10396. [CrossRef]

129. Jhaveri, A.; Deshpande, P.; Pattni, B.; Torchilin, V. Transferrin-targeted, resveratrol-loaded liposomes for the treatment of glioblastoma. J. Control. Release 2018, 277, 89-101. [CrossRef]

130. Sallem, F.; Haji, R.; Vervandier-Fasseur, D.; Nury, T.; Maurizi, L.; Boudon, J.; Lizard, G.; Millot, N. Elaboration of Trans-Resveratrol Derivative-Loaded Superparamagnetic Iron Oxide Nanoparticles for Glioma Treatment. Nanomaterials 2019, 9, 287. [CrossRef]

131. Mukherjee, S.; Baidoo, J.N.E.; Sampat, S.; Mancuso, A.; David, L.; Cohen, L.S.; Zhou, S.; Banerjee, P. Liposomal TriCurin, A Synergistic Combination of Curcumin, Epicatechin Gallate and Resveratrol, Repolarizes Tumor-Associated Microglia/Macrophages, and Eliminates Glioblastoma (GBM) and GBM Stem Cells. Molecules 2018, 23, 201. [CrossRef]

132. Neves, A.R.; Queiroz, J.F.; Reis, S. Brain-targeted delivery of resveratrol using solid lipid nanoparticles functionalized with apolipoprotein E. J. Nanobiotechnol. 2016, 14, 27. [CrossRef] [PubMed]

133. Shi, D.D.; Dong, C.M.; Ho, L.C.; Lam, C.T.W.; Zhou, X.D.; Wu, E.X.; Zhou, Z.J.; Wang, X.M.; Zhang, Z.J. Resveratrol, a natural polyphenol, prevents chemotherapy-induced cognitive impairment: Involvement of cytokine modulation and neuroprotection. Neurobiol. Dis. 2018, 114, 164-173. [CrossRef] [PubMed]

134. Singh, C.K.; George, J.; Ahmad, N. Resveratrol-based combinatorial strategies for cancer management. Ann. N. Y. Acad. Sci. 2013, 1290, 113-121. [CrossRef] [PubMed]

135. Lin, C.J.; Lee, C.C.; Shih, Y.L.; Lin, T.Y.; Wang, S.H.; Lin, Y.F.; Shih, C.M. Resveratrol enhances the therapeutic effect of temozolomide against malignant glioma in vitro and in vivo by inhibiting autophagy. Free Radic. Biol. Med. 2012, 52, 377-391. [CrossRef]

136. Yuan, Y.; Xue, X.; Guo, R.B.; Sun, X.L.; Hu, G. Resveratrol enhances the antitumor effects of temozolomide in glioblastoma via ROS-dependent AMPK-TSC-mTOR signaling pathway. CNS Neurosci. Ther. 2012, 18, 536-546. [CrossRef]

137. Goffart, N.; Kroonen, J.; Rogister, B. Glioblastoma-initiating cells: Relationship with neural stem cells and the micro-environment. Cancers 2013, 5, 1049-1071. [CrossRef]

138. Li, H.; Liu, Y.; Jiao, Y.; Guo, A.; Xu, X.; Qu, X.; Wang, S.; Zhao, J.; Li, Y.; Cao, Y. Resveratrol sensitizes glioblastoma-initiating cells to temozolomide by inducing cell apoptosis and promoting differentiation. Oncol. Rep. 2016, 35, 343-351. [CrossRef]

139. Ozdemir, F.; Apaydin, E.; Onder, N.I.; Sen, M.; Ayrim, A.; Ogunc, Y.; Incesu, Z. Apoptotic effects of epsilon-viniferin in combination with cis-platin in C6 cells. Cytotechnology 2018, 70, 1061-1073. [CrossRef]

140. Kma, L. Synergistic effect of resveratrol and radiotherapy in control of cancers. Asian Pac. J. Cancer Prev. 2013, 14, 6197-6208. [CrossRef]

141. Kao, C.L.; Huang, P.I.; Tsai, P.H.; Tsai, M.L.; Lo, J.F.; Lee, Y.Y.; Chen, Y.J.; Chen, Y.W.; Chiou, S.H. Resveratrol-induced apoptosis and increased radiosensitivity in CD133-positive cells derived from atypical teratoid/rhabdoid tumor. Int. J. Radiat. Oncol. Biol. Phys. 2009, 74, 219-228. [CrossRef]

142. Lu, K.H.; Chen, Y.W.; Tsai, P.H.; Tsai, M.L.; Lee, Y.Y.; Chiang, C.Y.; Kao, C.L.; Chiou, S.H.; Ku, H.H.; Lin, C.H.; et al. Evaluation of radiotherapy effect in resveratrol-treated medulloblastoma cancer stem-like cells. Child's Nerv. Syst. Chns 2009, 25, 543-550. [CrossRef] [PubMed] 
143. Yang, Y.P.; Chang, Y.L.; Huang, P.I.; Chiou, G.Y.; Tseng, L.M.; Chiou, S.H.; Chen, M.H.; Chen, M.T.; Shih, Y.H.; Chang, C.H.; et al. Resveratrol suppresses tumorigenicity and enhances radiosensitivity in primary glioblastoma tumor initiating cells by inhibiting the STAT3 axis. J. Cell. Physiol. 2012, 227, 976-993. [CrossRef] [PubMed]

144. Wang, L.; Long, L.; Wang, W.; Liang, Z. Resveratrol, a potential radiation sensitizer for glioma stem cells both in vitro and in vivo. J. Pharmacol. Sci. 2015, 129, 216-225. [CrossRef] [PubMed]

145. Seidu, R.A. The Therapeutic Potential of Resveratrol in Gliomas. Adv. Biosci. Clin. Med. 2019, 7, 44-59. [CrossRef]

146. Rauf, A.; Imran, M.; Butt, M.S.; Nadeem, M.; Peters, D.G.; Mubarak, M.S. Resveratrol as an anti-cancer agent: A review. Crit. Rev. Food Sci. Nutr. 2018, 58, 1428-1447. [CrossRef]

147. Varoni, E.M.; Lo Faro, A.F.; Sharifi-Rad, J.; Iriti, M. Anticancer Molecular Mechanisms of Resveratrol. Front. Nutr. 2016, 3, 8. [CrossRef]

148. Otto, T.; Sicinski, P. Cell cycle proteins as promising targets in cancer therapy. Nat. Rev. Cancer 2017, 17, 93-115. [CrossRef]

149. Filippi-Chiela, E.C.; Villodre, E.S.; Zamin, L.L.; Lenz, G. Autophagy interplay with apoptosis and cell cycle regulation in the growth inhibiting effect of resveratrol in glioma cells. PLoS ONE 2011, 6, e20849. [CrossRef]

150. Laaniste, L.; Srivastava, P.K.; Stylianou, J.; Syed, N.; Cases-Cunillera, S.; Shkura, K.; Zeng, Q.; Rackham, O.J.L.; Langley, S.R.; Delahaye-Duriez, A.; et al. Integrated systems-genetic analyses reveal a network target for delaying glioma progression. Ann. Clin. Transl. Neurol. 2019, 6, 1616-1638. [CrossRef]

151. Swartling, F.J.; Čančer, M.; Frantz, A.; Weishaupt, H.; Persson, A.I. Deregulated proliferation and differentiation in brain tumors. Cell Tissue Res. 2015, 359, 225-254. [CrossRef]

152. Castino, R.; Pucer, A.; Veneroni, R.; Morani, F.; Peracchio, C.; Lah, T.T.; Isidoro, C. Resveratrol reduces the invasive growth and promotes the acquisition of a long-lasting differentiated phenotype in human glioblastoma cells. J. Agric. Food Chem. 2011, 59, 4264-4272. [CrossRef] [PubMed]

153. Patial, S.; Blackshear, P.J. Tristetraprolin as a Therapeutic Target in Inflammatory Disease. Trends Pharmacol. Sci. 2016, 37, 811-821. [CrossRef] [PubMed]

154. Sanduja, S.; Blanco, F.F.; Young, L.E.; Kaza, V.; Dixon, D.A. The role of tristetraprolin in cancer and inflammation. Front. Biosci. 2012, 17, 174-188. [CrossRef] [PubMed]

155. Ryu, J.; Yoon, N.A.; Seong, H.; Jeong, J.Y.; Kang, S.; Park, N.; Choi, J.; Lee, D.H.; Roh, G.S.; Kim, H.J.; et al. Resveratrol Induces Glioma Cell Apoptosis through Activation of Tristetraprolin. Mol. Cells 2015, 38, 991-997. [CrossRef]

156. Huang, H.; Lin, H.; Zhang, X.; Li, J. Resveratrol reverses temozolomide resistance by downregulation of MGMT in T98G glioblastoma cells by the NF-kB-dependent pathway. Oncol. Rep. 2012, 27, 2050-2056. [CrossRef]

157. Yang, H.C.; Wang, J.Y.; Bu, X.Y.; Yang, B.; Wang, B.Q.; Hu, S.; Yan, Z.Y.; Gao, Y.S.; Han, S.Y.; Qu, M.Q. Resveratrol restores sensitivity of glioma cells to temozolamide through inhibiting the activation of Wnt signaling pathway. J. Cell. Physiol. 2018, 234. [CrossRef]

158. Filippi-Chiela, E.C.; Thomé, M.P.; Bueno e Silva, M.M.; Pelegrini, A.L.; Ledur, P.F.; Garicochea, B.; Zamin, L.L.; Lenz, G. Resveratrol abrogates the Temozolomide-induced G2 arrest leading to mitotic catastrophe and reinforces the Temozolomide-induced senescence in glioma cells. BMC Cancer 2013, 13, 147. [CrossRef]

159. Hu, Y.; Li, C.; Li, H.; Li, M.; Shu, X. Resveratrol-mediated reversal of tumor multi-drug resistance. Curr. Drug Metab. 2014, 15, 703-710. [CrossRef]

160. Lee, S.; Lee, J.S. Cellular senescence: A promising strategy for cancer therapy. Bmb Rep. 2019, 52, 35-41. [CrossRef]

161. Zeng, S.; Shen, W.H.; Liu, L. Senescence and Cancer. Cancer Transl. Med. 2018, 4, 70-74. [CrossRef]

162. Gao, Z.; Xu, M.S.; Barnett, T.L.; Xu, C.W. Resveratrol induces cellular senescence with attenuated mono-ubiquitination of histone H2B in glioma cells. Biochem. Biophys. Res. Commun. 2011, 407, 271-276. [CrossRef] [PubMed]

163. Vargas, J.E.; Filippi-Chiela, E.C.; Suhre, T.; Kipper, F.C.; Bonatto, D.; Lenz, G. Inhibition of HDAC increases the senescence induced by natural polyphenols in glioma cells. Biochem. Cell Biol. 2014, 92, 297-304. [CrossRef] [PubMed] 
164. Sayd, S.; Thirant, C.; El-Habr, E.A.; Lipecka, J.; Dubois, L.G.; Bogeas, A.; Tahiri-Jouti, N.; Chneiweiss, H.; Junier, M.P. Sirtuin-2 activity is required for glioma stem cell proliferation arrest but not necrosis induced by resveratrol. Stem Cell Rev. Rep. 2014, 10, 103-113. [CrossRef] [PubMed]

165. Yang, Y.; Cui, J.; Xue, F.; Overstreet, A.M.; Zhan, Y.; Shan, D.; Li, H.; Li, H.; Wang, Y.; Zhang, M.; et al. Resveratrol Represses Pokemon Expression in Human Glioma Cells. Mol. Neurobiol. 2016, 53, 1266-1278. [CrossRef]

166. West, A.J.; Tsui, V.; Stylli, S.S.; Nguyen, H.P.T.; Morokoff, A.P.; Kaye, A.H.; Luwor, R.B. The role of interleukin-6-STAT3 signalling in glioblastoma. Oncol. Lett. 2018, 16, 4095-4104. [CrossRef]

167. Kim, J.E.; Patel, M.; Ruzevick, J.; Jackson, C.M.; Lim, M. STAT3 Activation in Glioblastoma: Biochemical and Therapeutic Implications. Cancers 2014, 6, 376-395. [CrossRef]

168. Ganguly, D.; Fan, M.; Yang, C.H.; Zbytek, B.; Finkelstein, D.; Roussel, M.F.; Pfeffer, L.M. The critical role that STAT3 plays in glioma-initiating cells: STAT3 addiction in glioma. Oncotarget 2018, 9, 22095-22112. [CrossRef] [PubMed]

169. Sherry, M.M.; Reeves, A.; Wu, J.K.; Cochran, B.H. STAT3 is required for proliferation and maintenance of multipotency in glioblastoma stem cells. Stem Cells 2009, 27, 2383-2392. [CrossRef] [PubMed]

170. Brescia, P.; Ortensi, B.; Fornasari, L.; Levi, D.; Broggi, G.; Pelicci, G. CD133 is essential for glioblastoma stem cell maintenance. Stem Cells 2013, 31, 857-869. [CrossRef] [PubMed]

171. Ray, S.; Coulter, D.W.; Gray, S.D.; Sughroue, J.A.; Roychoudhury, S.; McIntyre, E.M.; Chaturvedi, N.K.; Bhakat, K.K.; Joshi, S.S.; McGuire, T.R.; et al. Suppression of STAT3 NH2-terminal domain chemosensitizes medulloblastoma cells by activation of protein inhibitor of activated STAT3 via de-repression by microRNA-21. Mol. Carcinog. 2018, 57, 536-548. [CrossRef] [PubMed]

172. Li, C.; Li, H.; Zhang, P.; Yu, L.-J.; Huang, T.-M.; Song, X.; Kong, Q.-Y.; Dong, J.-L.; Li, P.-N.; Liu, J. SHP2, SOCS3 and PIAS3 Expression Patterns in Medulloblastomas: Relevance to STAT3 Activation and Resveratrol-Suppressed STAT3 Signaling. Nutrients 2016, 9, 3. [CrossRef] [PubMed]

173. Muller, P.A.J.; Vousden, K.H. Mutant p53 in cancer: New functions and therapeutic opportunities. Cancer Cell 2014, 25, 304-317. [CrossRef] [PubMed]

174. Zhang, Y.; Dube, C.; Gibert, M., Jr.; Cruickshanks, N.; Wang, B.; Coughlan, M.; Yang, Y.; Setiady, I.; Deveau, C.; Saoud, K.; et al. The p53 Pathway in Glioblastoma. Cancers 2018, 10, 297. [CrossRef] [PubMed]

175. Song, M.; Bode, A.M.; Dong, Z.; Lee, M.-H. AKT as a Therapeutic Target for Cancer. Cancer Res. 2019. [CrossRef] [PubMed]

176. Lin, H.; Xiong, W.; Zhang, X.; Liu, B.; Zhang, W.; Zhang, Y.; Cheng, J.; Huang, H. Notch-1 activation-dependent p53 restoration contributes to resveratrol-induced apoptosis in glioblastoma cells. Oncol. Rep. 2011, 26, 925-930. [CrossRef] [PubMed]

177. Sato, A.; Okada, M.; Shibuya, K.; Watanabe, E.; Seino, S.; Suzuki, K.; Narita, Y.; Shibui, S.; Kayama, T.; Kitanaka, C. Resveratrol promotes proteasome-dependent degradation of Nanog via p53 activation and induces differentiation of glioma stem cells. Stem Cell Res. 2013, 11, 601-610. [CrossRef]

178. Pu, P.; Zhang, Z.; Kang, C.; Jiang, R.; Jia, Z.; Wang, G.; Jiang, H. Downregulation of Wnt2 and beta-catenin by siRNA suppresses malignant glioma cell growth. Cancer Gene Ther. 2009, 16, 351-361. [CrossRef]

(C) 2020 by the authors. Licensee MDPI, Basel, Switzerland. This article is an open access article distributed under the terms and conditions of the Creative Commons Attribution (CC BY) license (http://creativecommons.org/licenses/by/4.0/). 